\title{
Minimalisme i TV-reklamen
}

Det særlige ved TV-reklamen er den ultrakorte tidsmæssige ramme. TV-spots skal levere budskabet i løbet af 10-30 sekunder. I den henseende kan de have visse ligheder med andre dele af TV-fladen, hvor det samme tidspres g $\phi_{\mathrm{r}} \mathrm{sig}$ gældende f.eks. TV-nyhederne. I en anden henseende er der også træk ved TV-spottene, som breder sig til programmerne. For at undgă zapping kan man se en vis tendens i nogle programmer (f.eks. ungdomsprogrammer) til at skære forløb og udsagn op i mindre og mindre bidder, så man opnår et passende flow af varieret, dynamisk distraktion i det enkelte program. Men i en anden henseende står TV-spots som raptpointercde kortformer også i direkte modsætning til en stor del af det omgivende programmateriale. Især i takt med at snakkeog samtaleprogrammer og andre studieprogrammer som f.eks. game-shows breder sig på programfladerne.

Hensigten i det projekt, som det følgende er en del af, ${ }^{1}$ er derfor dels at anskue TV-spots som en særlig genre, dels at se dem i forhold til det øvrige programmateriale.

\section{Indledende om det minimale}

Set over årene og set $\mathrm{i}$ international sammenhæng cr TV-spottet generelt blevet kortere og kortere. Spots på 60 sekunder er en sjældenhed i dag, mens spots på 10-20 sekunder på ingen måde er ualmindelige. Dette tidsmæssige pres har nogle indlysende konsekvenser. For det første bliver det vanskeligt at omforme reklamens budskab til små underholdende spil eller dramaer, eftersom der normalt skal mindst 25-30 sekunder til, for at dette kan lade sig gøre. Alt andet lige er konsekvensen, at spots, som spiller op til publikums egen slutningsevne og forestillingsverden, făr problcmer, når tidsrammen bliver kort, mens spots, som på en mere håndfast og belærende måde direkte fortæller publikum budskabet, automatisk vil blive alternativet. For det andet: i det omfang TV-spots er organiseret $\mathrm{i}$ blokke, vil der også opstå et problem med, at blokkene bliver mere og mere forstyrrede, og at budskaberne interfererer med 
hinanden i takt med, at den hastighed, hvormed forskellige mærker, budskaber og spotudformninger blæses ud i hovedet på publikum, stiger.

Tidspresset på TV-spottet rejser således et spørgsmål om, hvordan det er muligt at variere disse minimale formater, især eftersom variation og forskelligartethed udgør nogle af de helt centrale kilder i reklamens generelle konkurrence om opmærksomhed. Dette problem skal også ses i lyset af de særlige problemer, som TV-reklamen har p.g.a. gentagelsesfaktoren og den dermed forbundne nedslidning. Man kan formulere problemet på følgende mere informationstekniske måde: i kampen mod tiden og tidspresset og i opmærksomhedskonkurrencen med de $\emptyset$ vrige spots må TV-spottet som genre udfinde kommunikationsmåder, hvor inputtet er minimalt, mens outputtet - set i forhold til publikum - er maksimalt. Minimeringen af information forstået i form af bits og maksimeringen af information forstået som det, disse bits kan udvirke i publikums hoveder, er, hvad jeg vil kalde, både problemet og den kreative kilde i den minimalisme, som TV-spottet er underkastet. Hvad der er kort, skal blive langt. Hvad der er tyndt, skal blive fyldigt.

For at give et endda meget kort eksempel, der kan belyse problemstillingen ret så håndfast, kan man tage et ekstremt spot på kun 5 (fem) sekunders varighed. I dette spot (fra april 1989), som er det korteste, jeg overhovedet har kunnet opdrive, viser billedsiden de $\emptyset$ kologiske pita brød og deres emballage fra Stenmøllen. Mens korn hældes ned over dette stilleben og kameraet zoomer ind pă pakningen høres i voice-over en mandlig røst. Stemmen, der er præget af en drævende jysk dialekt, fortæller os ganske jævnt og simpelt: »Stenmøllepita. Brune - sunde. Af usprøjtet korn. Slut. Jeg har kun råd til 5 sekunder «. Den allersidste bemærkning, som på et plan peger på selve kommunikationskanalen, mediet og genren, men som på et andet plan også kan underforstå en ikke udtalt pointe om et modsætningsforhold mellem en (personbunden) $\emptyset$ kologisk produktion, der på ingen måde er særlig profitabel, og en TV-reklame, som generelt kræver en helt anderledes voldsom $\emptyset$ konomisk styrke, kan dermed siges at være et minimalt udtryk eller input med et maksimalt indhold eller output. Hvad enten det nu har været hensigten eller ikke, så kan bemærkningen sætte gang i en hel forståelsesramme og aktualisere et felt af givne underforståede kulturelle betydninger, som formentlig endda også er relevante og kongruente $\mathrm{i}$ forhold til netop dette produkt og dets brugere i et bredere perspektiv.

Skønt der er tale om et ekstremt eksempel, der kan vise det minimale, både hvad angår tid, og hvad angår minimalismens forsøg på at få det maksimale output, så er dette spot i andre henseender eksemplarisk med hensyn til dansk TV-reklame. I hvilket omfang det er eksemplarisk, vil en del af denne undersøgelse søge at belyse igennem en kvantitativ kategorisering af TV-spots siden 
1989. En anden del vil forsøge at gå mere i detaljen og gå mere kvalitativt til værks i forhold til den fremherskende form inden for TV-spot reklamell (som skal vise sig formelt set at være identisk med den ovenstående) i den hensigt at vise de forskelligartede og måske endda sofistikerede måder, hvorpå der opereres i denne form og dermed også angive nogle mere generelle indikatorer vedrørende det kreative potentiale i dette format.

Før vi går nærmere ind på dette, finder jeg det imidlertid fornødent at ofre både spørgsmålet om minimalisme og om de generelle problemer, som gør sig gældende i forbindelse med TV-reklame, en smule mere opmarksomhed.

\title{
Minimalisme og de generelle betingelser vedr. TV-spots
}

Minimalisme er på ingen måde et begreb med en ganske afklaret eller videnskabelig status. Jeg bruger begrebet i denne sammenhæng som en deskriptiv term til at angive nogle af de generelle principper, der styrer reklame og især reklame i TV.

Minimalisme kan have forskellige baggrunde og udspring. I TV-spots er tid penge, sådan som det klart er blevet demonstreret i 5-sekunders spottet ovenfor. Sammenhængen mellem $\emptyset$ konomi i almindelig forstand og betydningsфkonomi er ganske klar. Og det er på ingen måde arbitrært, at betegnelsen er 'spot'.

Men når man taler om minimalisme $\mathrm{i}$ en kunstnerisk og mere almen sammenhæng, dvs. som almindelig æstetisk ambition og som et afgørende etisk krav i forbindelse med kommunikation og information, er de minimale måder at udtrykke sig på værdifulde i sig selv. Pointen er, at det drejer sig om at barbere, presse og raffinere udtrykket ned til de absolut nødvendige elementer og påregne, at publikum selv er i stand til at danne betydning ud fra disse minimale og essentielle størrelser. Men også at det drejer sig om at give tingene en form eller struktur, der støtter og styrker det semantiske indhold. Japansk Haiku-digtning er en illustrativ representant for ambitioner af denne type.

\author{
En gammel \\ dam \\ En frø \\ springer \\ Plask
}


Som i denne form for poesi har poesi generelt en indbygget tendens eller et indbygget krav om koncentration on det essentielle. Læseren overlades arbejdet med at danne betydningen i videre forstand. Og for at forhøje og forstærke indholdet og gøre det huskeligt er den poetiske funktions minimalismer af afgørende betydning (jf. f.eks. epigrammet), som også reklamen har indset næsten fra allerførste færd.

Den samme $x$ stetiske tendens findes i fragmentet som kunstnerisk form, $i$ sagaen, i impressionistisk prosa, i Charlie Rivels klovnefigur, hos komikere som Victor Borge, så vel som i moderne kunst, design og arkitektur.

Minimalisme udgør også cn vigtig dimension af hverdagslivet: vittigheder, aforismer, ordspil, gåder, underforståetheder, allusioncr, talemåder, ordsprog, antydninger, men også i massekulturelle kunstformer som er tæet på hverdagslivet som f.eks. stand-up comedy og TV-comedy. Vi er inde på et område, hvor den ultra-korte historie, situationen og det korte, fortættede udtryk ganske meningsfuldt gemmer sin intention om at udvirke det direkte modsatte af udtrykkets form iblandt publikum. Hvad der normalt sammenfattes i en kognitivistisk tankegang om skemaer/schemata og skemaaktiverende elementer, spiller en afgørende rolle, hvor minimalismen er på spil. ${ }^{2}$

I forhold til audiovisuelle forl $\varnothing \mathrm{b}$ i al almindelighed er minimalisme vigtig som et forhold, der sparer tid og fortætter betydning via kameravinkler og -bevægelser, nærhed-afstand, klip og montage og via scenografiens forskellige lag af informationer samt kombinationerne af lyd og billede.

TV-reklamen er tvunget til at tilpasse sig og udvikle minimalistiske former af økonomisk nødvendighed (tidspresset), men også af grunde som kunne kaldes et generelt kulturelt krav til reklamen i almindelighed. Reklame er ikke blot et spørgsmål om information om produkt, pris og salgssted i ren referentiel forstand. Det er også et spørgsmål om information om, hvordan man informeres eller information om selve informationsprocesseringen, måden hvorpå informationer gives.

Igennem det 20. århundrede har reklamen selv lært sit publikum at forvente ikke blot nye produkter, men også nye, spektakulære og sensationelle måder at informere om produkter på. Og i takt med at det første er taget af, er det sidste taget til. Dette skyldes ikke kun, at konkurrencen mellem produkter i højere og højere grad er blevet en konkurrence om at vinde offentlighedens opmærksomhed og publikums bevidsthed, og at reklamen derfor må tilføre noget ekstra, noget som appellerer til andre og bredere dimensioner af publikums erfaringshorisont. Det hænger også sammen med tvetydighederne i information som sådan: at man ofte glemmer, at information ikke er et én-til-én fænomen på grund af de tegnsystemer, som er bærere af informationen, og som i de fleste tilfælde samtidig er bærere af et multiplum af forskelligartede kommuniki- 
tive funktioner. Én af dem er deres evne til at referere til sig selv og måderne at referere på og dermed det forhold, at de ikke blot refererer til fæenomener $\mathrm{i}$ verden. På samme måde som der er tale om information, når det nye og uventede skcr, vokscr informationsværdien i takt med dens uforudsigelighed. Dette vedrører ikke kun, hvad der refereres til, men i lige så høj grad måden hvorpå denne reference bliver til. Som enhver anden informationsvirksomhed er reklame dermed underlagt en udvikling med hensyn til kreativitet, et krav om sofistikering i udformningen af informationerne og et krav om konstante fornyelser i de måder, hvorpå man søger at skabe sympati. Set $i$ det perspektiv udvikler reklame (mærkevarereklame) i lighed med andre tekstuelle og symbolske fænomener, der har en afgørende samfundsmæssig gennemslagskraft af institutionel karakter, en egen symbolsk og æstetisk verden med sine egne cyklusser ${ }^{3}$ i lige så høj grad, som den også indoptager og udnytter andre tekstlige og symbolske verdener. I dette spil står reklamen til gengæld overfor den ikke altid forligelige spænding mellem bogholderens tankegang og kreatørens. Reklame skal kommunikere og være informativ, men den skal først og fremmest sørge for at sælge billetter.

Skønt reklamen er storforbruger af andre kunstneriske udtryksmåder, er reklame ikke dermed kunst eller poesi eller drama. Reklame er først og fremmest massekommunikation. Den har om noget karakter af en uopfordret henvendelse med en forholdsvis snæver og kalkuleret hensigt, der går ud på at skabe opmærksomhed og sympati i forhold til et produkt eller en ydelse. Som sådan er den begrænset af tre forhold: På trods af den snævre hensigt og store chancer for at blive stemplet som anmassende skal den appellere til store publikumsgrupper eller offentligheder - også selv om disse er indsnævret i form af mere specifikke målgrupper. Måderne, hvorpå der appelleres til publikum, skal være relevant og i overensstemmelse med væsenstræk ved mærket/produktet, dets brug og dets brugere. Endelig slides den konkrete reklameudformning hurtigt op - først og fremmest på grund af gentagelsen. Reklamen må derfor bestandig finde nye måder, hvorpå den samme gamle historie kan fortælles og søge at $\emptyset$ ge slidstyrken f.eks. ved at udvikle koncepter, der muligg $\varnothing \mathrm{r}$ variation over samme idé, tcma eller grundmønster.

TV-reklame spots er sâledes underkastet en række af de betingelser, som generelt styrer reklamen: kravet om nye måder mht. hvordan information gives og fortættes, kravet om slidstyrke, modsætningen mellem offentlig fremtræden og snæver hensigt. Det særlige ved TV-spot reklamen er det tidspres, som den er underkastet.

Svaret på tidspresset som generelt problem kan illustreres ved et kontinuum udspændt mellem to ekstremer m.h.t. relationen mellem tid/indhold. I den ene ende af skalaen finder vi en udformning, som understreger hast(ighed) og der- 
med også udtrykker de generelle betingelser: hurtigsnak, hurtigklipning, sammenpresning for at få så meget verbal, visucl, lydlig information med som mulig, men også for at få spottet til at virke så overvældende, dynamisk og stakåndet underholdende og varieret som muligt. I den anden ende finder man en bevidst meget langsom form: ganske få udsagn, næsten ingen handling og optagelse typisk i en fast kamera/sekvensindstilling. Det langsomme ekstrems funktion går selvsagt ud på at skabe plads og rum omkring dette spot blandt spots og f.eks. sørge for ro til publikums egen bevidsthedsmæssige aktivitet. Men det går også helt elementært ud på at skabe en forskel og en kontrast til den højhastighed, som typisk karakteriserer gennemsnittet blandt de omkringliggende spots.

Et andet svar ligger i den almindelige brug af velbekendte (adfærds)skemaer, temaer, myter, genrer, symboler og dagsordener. Dette er ikke noget særkende for TV-reklamer, men et generelt træk ved reklame. Og det samme kan siges om det tredje svar på spot-formens tidspres: brugen af æstetikkens kortformer som f.eks. vits, fortællefragment, ultra short story, situation(skomedie), ordsprog, anekdote, ordspil, samt brugen af retorikkens grundfigurer: metafor, metonym, sammenligning, omvending, litote, ellipse osv. ${ }^{4}$

TV-reklamespots er udenfor sammenligning med andet audiovisuelt materiale på i hvert fald et punkt: ved at blive vist igen og igen og igen. Gentagelse er det almindelige vilkår og nedslidning det lige så uundgåelige resultat. Som i trykt annoncering og som det også gør sig gældende i TV-produktion i øvrigt (TV-serier), er konstruktionen af spots på basis af et fast koncept en af løsningerne på dette problem. Et sådant koncept eller en sådan serie-form muligg $ø$ r, at man kan variere og samtidig fastholde den grundlæggende struktur og idé, typisk som man gør det i et tema (der ofte er forankret $i$ et slogan) med variationer. Pă denne måde er det muligt at omgå nogle af de problemer, som er forbundet med tidspresset og gentagelserne og måske endda få noget af den samme effekt, som mange TV-serier og faste programformater har: en slags kontinuitet og kontinuerlig opbygning på tværs af de enkelte forskellige spots og et indforstået publikum, som er parat til at give sig i kast med 'den næste episode’ og glæde sig over både det velkendte og det nye. »Merrild sætter smag på hele din dag « (små dramatiske situationer med problemer og glæder i dagliglivet) og til dels også den gennemført minimalistiske »Det handler om at være TRYG« er eksempler på koncepter, som har fungeret nogenlunde uændret siden dansk TV-reklames allerførste start i 1987.

Men i forbindelse med TV-spots findes også en anden og mere særegen vej til variation og tidsbesparelse. Enten ved at producere en fragmenteret udgave (10-15 sekunder) af et oprindeligt længere spot (30-40 sekunder) - uanset om dette oprindelig var struktureret syntagmatisk (som f.eks. drama eller fortæl- 
ling) eller paradigmatisk (som f.eks. lyrik). Eller - da forkortelsen af et fortællende spot selvsagt kan give problemer mht. de årsag-virkningskæder, som normalt indgår i visualiserede fortællinger - ved at strukturere spottet overvejende paradigmatisk, sådan at det kan varieres og gфres både kortere og længere ved, at man simpelt hen indsætter nye klip eller ændrer rækkefølgen i montagen.

Den specifikke udformning af det enkelte spot er selvfølgelig nødt til at tage hensyn til forhold, som intet har med selve spot-formen at gøre. Det kan f.eks. være helt afgørende, hvor det pågældende produkt eller mærke befinder sig i forhold til produktlivscyklus: er det $\mathrm{i}$ introduktions-, vækst- , modenhedseller nedgangsfase. På samme måde er målgruppen og dens kulturelle ballast også afgørende. Endelig kan det være af afgørende betydning, hvis spottet skal spille en bestemt rolle i det samlede mediemix i en markedsføringsstrategi. Alle disse aspekter vil imidlertid ikke blive inddraget her.

I det $\not \varnothing l g e n d e$ er det først og fremmest TV-spottet som et særligt minimalistisk audio-visuelt fænomen, som er i focus. Dvs. som et synæstetisk fænomen, der samordner lyd, tale, billedforl $\emptyset \mathrm{b}$ og grafiske elementer, og som derfor giver mulighed for at efterligne oplevelser af virkeligheden på en meget livagtig måde. Reklame på TV betragtes som meget mere effektiv end i noget andet medium - bl.a. på grund af de synæstetiske faktorer, der bevirker, at der tales til mere end én sans, men selvfø̆lgelig også fordi man via dette medium meget hurtigt kan nå meget store grupper.

Reklame i TV omgærdes derfor af særlige restriktioner og var i det hele taget bandlyst $\mathrm{i}$ de første 25 år af dansk TV's levetid. Det er først fornylig (1988), at alle danskere har fået mulighed for at se, elske og/eller hade reklamer på TV. TV-spottet, der på dansk grund er et relativt nyt fæænomen, har imidlertid hurtigt vist sig at blive et program(flade)fænomen af betragtelige dimensioner.

\section{Kort om den historiske baggrund og TV-reklamens omfang}

TV-reklame på dansk starter i realiteten allerede i efteråret 1987, hvor TV-Syd som den eneste oprettede inden for TV2-systemet begynder at sende reklameblokke. Men reklamen bliver i princippet først landsdækkende i efteråret 1988, da TV2 begynder at sende. TV2 er som bekendt oprettet som et blandingsfinansieret public service foretagende, hvis indtægter både skal komme fra salg af reklametid (via det særlige reklameselskab TV2 Reklame A/S) og fra licens. Man skal frem til 1992, før der for alvor kommer volumen på rekla- 
men, og den alt $i$ alt bliver den indtjeningsfaktor, som den var udset til at skulle blive. Det hænger sammen med, at reklamen til en begyndelse var kraftigt indskrænket. Oprindelig til kun at skulle bestå i et par 5 minutters reklameblokke på hver side af Nyhederne. Derefter fik man lov til at $\emptyset$ ge med flere blokke på programfladen. I 1992 ophørte disse bindinger mht. blokantal, således at blokke kunne placeres frit på programfladen, blot den samlede reklametid ikke oversteg $10 \%$ af den samlede programsendetid. Samtidig fik man via TV-Meter målingerne et meget mere præcist billede af publikum.

TV-reklamen er i dette forl $\varnothing b$ blevet til en omfattende del af programfladen. I 1993 udgjorde den săledes i gennemsnit 4 timer pr. uge, og i 1994 var de 4 timer blevet til 4,5 time. Hertil kommer, at mindst 3,5-4 timer pr. uge var besat med stationens egenreklame (trailers, forskræp mv.). Over 8 timer om ugen er dermed besat af reklamen og spot-formen på den ene eller anden måde. Spotformen er blevet et tungtvejende programmateriale. Reklame og egenreklame fylder på ugebasis mere end TV-nyhederne, som andrager 5-6 timer pr. uge.

\section{Undersøgelsens rammer og hensigt}

Hensigten med den følgende unders $\emptyset$ gelse er at få et overblik over en del af dette omfattende materiale, ${ }^{5}$ nemlig TV-reklame spottet og at gøre det over 6 års horisont og med basis i TV2-materiale. Ikke alle aspekter vil blive inddraget. Hvad der først og fremmest vil blive fokuseret på er, hvordan dette audiovisuelle materiale henvender sig til publikum og efter hvilke hovedformler, det gør det. Genreproblemstillinger spiller således en stor rolle.

At fremskaffe et overblik kunne for så vidt i sig selv vare interessant, fordi der er tale om et meget stort antal og øjensynligt meget forskellige 'tekster' (af nemhedsgrunde vælger jeg i det følgende at referere til spottene med denne term, uanset at der selvsagt ikke er tale om tekster i ordets egentlige betydning). Hen over årene er der tale om ca. 1000 (i 1989) til ca. 2500 (i 1994) forskellige spots. Af dem er 20-35\% udenlandske, der som regel er versionerede, mens 80-65\% er af dansk(produceret) oprindelse. Spots af dansk oprindelse har haft en faldende andel (jf. senere).

Men spørgsmålet er, hvor forskelligartede disse spots egentlig er, og det er et af kærnespørgsmålene, når man anskuer TV-spots som tekster eller symbolske manifestationer, der konkurrerer om at vinde opmærksomhed. At kunne skabe forskelle, at kunne distingvere sig spiller en altafgørende rolle i reklame.

Som alle andre tekster er reklame-spots styret rammemæssigt af bestemte henvendelsesformer og måder at udtrykke sig på. For at sige det kort er de styret af bestemte genrer, formularer eller formater. Uanset den øjensynlige 
forskelligartethed er spottene nødvendigvis tvunget til i et eller andet omfang at indordne sig under bestemte formater eller henvendelsestyper. Men hovedproblemet forsvinder jo ikke af den grund: i hvilket omfang underlægger spottene sig bestemte formater, i hvilket omfang afviger de fra det gangse? I hvilket omfang bliver en bestemt form fremherskende? Man kan også formulcre problemet lidt mere radikalt: hvis alle fremsatter deres budskab/tilbud på samme eller næsten samme måde, kan man risikere, at ingen lytter. Formen bliver triviel.

Hensigten er dermed ikke blot at give en oversigt over materialet så at sige for dets egen skyld, men også at undersøge om bestemte former eller typer cr over-repræsenterede, og om der er 'huller' og udviklingsmuligheder i det kreative landskab, som dannes af formaterne. Når vi taler om kreativitet, må det vel i denne sammenhæng også være på sin plads at nævne, at reklamebranchen såvel som offentligheden ret konstant har beklaget sig over mangelen på kreativitet og nytænkning i dansk TV-reklame. Det er f.eks. betegnende, at diverse udgaver af det samme spot-koncept (Tuborg Squash) har vundet prisen som bedste spot $i$ alle årene 1989-94. Der er ganske vist tale om et formidabelt godt spot, men at ingen andre i så lang en periode har kunnet slå det af pinden, kunne også ses som et symptom på, at »Something is rotten in the state of Denmark «, for så vidt angår TV-reklamer. Bevidstheden om, at det kunne forholde sig således, har i hvert fald fået TV2 Reklame til at indstifte en pris for Månedens bedste spot og til at hæve priserne betragteligt for f.eks. de korte 10 sekunders spot (begge dele fra 1993) og relativt set sænke prisen for de lange spots. Dette er bl.a. sket for at gøre det mindre attraklivt at levere et (ofte højtråbende) discount-budskab, der kun buldrer af sted med produkt, pris og salgssted.

Set i lyset af ovenstående kan den formmæssige variationsgrad eller manglen på variation være en indikator med hensyn til, hvordan det forholder sig med kreativitet og opfindsomhed på feltet: dansk TV-reklame og i det følgende vil da også først og fremmest den danskproducerede reklame varre i fokus.

For at skabe et overblik må man nødvendigvis begrænse sig til et udsnit, et 'sample' i forhold til det samlede materiale. Ligeledes er det nødvendigt forlods at opstille et antal kategorier, der er velegnede til at skandere materialet. Problemerne vedrørende materialeudsuit og kategorisering vil blive behandlet nøjere nedenfor. Et mere principielt problem mht. kategorisering skal imidlertid have et par ord med på vejen allerede her. Năr man nemlig opstiller en kategorisering, konstruerer man også et billede/en forestilling om materialet, som er baseret på bestemte antagelser og formodninger. Materiale af den her omhandlede type er imidlertid ikke statisk. Og selv om kategoriseringer kan give os en vis instrumentel orden på et kvantitativt niveau, så er de sjældent $i$ 
stand til omfatte de finere nuancer, som gør sig greldende i et materiale. En given kategorisering på symbolske produkter er således sjældent udtømmende. Hvis man imidlertid gennemfører kategoriseringen med skyldig respekt overfor materialet, kan den givne kategorisering afsløre nye aspekter og nye former. Så kan man naturligvis anklage den for utilstrækkelighed. Det er formentig mere produktivt at erkende, at enhver form for kategorisering har sine klare begrænsninger, og at en given kategoriserings formål - ud over at give et nogenlunde sikkert overblik - først og fremmest er at give en indikation på de basale tendenser i et materiale.

\section{Opsummerende: hensigten er}

- at skabe et overblik over reklamespottet de seneste 6 år (1989-94) igennem en kategorisering, som fokuserer på genrekarakteristika, og det vil i denne sammenhæng først og fremmest sige genrekarakteristika, sådan som de kan bestemmes via henvendelsesformen

- at gøre dette med henblik på at finde indikatorer på, i hvilket omfang danske TV-spots har tendens til at anvende stort set samme henvendelsesform, og i hvilket omfang de divergerer. Dette kan også være en indikator på graden af konformitet/trivialitet over for graden af kreativitet

- at gøre det muligt at opdage nye tendenser via selve kategoriseringen og de medfølgende spørgsmål og problemer, som en kategorisering altid vil udvirke vis-à-vis et dynamisk materiale.

\section{Og undersøgelsen hviler på følgende antagelser}

- at annonc $\varnothing$ rer, som 1) er i stand til give deres budskab en anden udformning end den fremherskende og som 2) via udformningen formår at give publikum mulighed for at drage deres egne slutninger eller på anden måde provokerer til aktivitet under tilegnelsesprocessen, alt andet lige er i besiddelse af en fordel, i det omfang reklame først og fremmest er et spørgsmål om en konkurrence om opmærksomhed og sympati, dvs. for så vidt det er vigtigt for annoncøren at besætte dele af den offentlige bevidsthed og den symbolske betydningsdannelse.

\section{Materialeudsnit og unders $\varnothing$ gelsesgrundlag}

Materialeudsnittet udgøres af en måneds reklamer i årene 1989, 1992 og 1994. TV2 Reklame har stillet »Månedens nye TV-reklamer« til rådighed for mig 
for disse år som helhed. Tal på visninger er i princippet også tilgængelige fra TV2 Reklame, men da disse kræver særkørsler, og da indrykningerne i én måned ikke er identisk med den tilsvarende måned, sådan som den fremtræder i »Månedens nye TV-reklamer«, tager nærværende undersøgelse ikke højde for antallet af .visninger. Dette betyder, at et spot, som teoretisk set kunne have været vist kun én gang, tæller lige så meget som ét, der har været vist adskillige gange. Dette forhold har ikke nogen afgørende indflydelse på den grundlaggende hensigt i undersøgelsen, eftersom hovedmålet er et finde indikatorer på bestemte fremherskende reklameformater, herunder indikatorer på mangfoldigheden og det kreative niveau. Men det kunne uden tvivl være interessant at foretage cn anden undersøgelse, som var baseret på de faktiske indrykninger, eftersom en sådan ville kunne enten forstærke eller svække det mønster, som vil fremgå på basis af »Månedens nye TV-reklamer «.

Eftersom hensigten er at undersøge, om der er sket afgørende ændringer over årene, valgte jeg én bestemt måned, nemlig april 1989, 1992 og 1994. Når valget faldt på april, hænger det sammen med, at april er en forholdsvis neutral måned forståct på den måde, at der ikke er tale om særlige begivenheder, som influerer på TV-reklamen som f.eks. udsalg eller julehandel, ligesom den heller ikke er præget af sæson (som f.eks. juni, juli, august). Ligeledes er der tale om en måned, hvor antallet af nye spots er tæt på gennemsnittet og udgør ca. $10 \%$ af arets samlede nye spots.

\section{Kategorisering og genre}

TV-spots og reklameudformningcr kan kategoriseres på flere måder. Der er da også udført er omfattende arbejde på omrädet. ${ }^{6}$ Set med genreteoretiske briller mangler de fleste af disse tilgange imidlertid konsistens. Det er uden tvivl berettiget at hævde, at specifikke typer eller formater som f.eks.: talsmanden (testimonial, presenter, announcer), produktpræsentation eller dokumentation, slice-of-life, reason-why og problemløsning udgør faste formater, som er vokset ud af reklamens arbejde inden for trykte, auditive og audiovisuelle medier. I hvert fald er de veletablerede formater i den forstand, at alle refererer til dem og uden videre kategoriserer på den måde.

Hvad der imidlertid komplicerer tingene, er, at reklamen kan betjene sig af en hvilken som helst genre. I højere grad end massekommunikation i almindelighed er reklamen nødt til at bruge og besinde sig på velkendte måder at henvende sig til publikum på og velkendte måder at forstå og at udtrykke sig på. Det hænger bl.a. sammen med den korte tid, der er til rådighed. Men omvendt 
er reklamen også tvunget til at forny, fordreje og radikalisere det velkendte for at få opmærksomhed (attention).

Som reklame i al almindelighed er TV-reklamen en parasitær genre, som bestandig bevæger sig i et spil med andre genrer, med »ting og temaer, der er oppe i tiden «, men ofte også i former, der parafraserer reklamens egne udtryksformer og talemåder. Det intertekstuelle spiller en stor rolle, og selv om intertekstualitet ikke er noget specielt for reklamen, så har spillet på intertekstuelle referencer en høj prioritering. ${ }^{7}$

Selv om reklamebranchen har skabt nogle særlige formater, som man uproblematisk refererer til i selvforståelsen, og selv om reklamen spiller ind på gangbare tekstformer, er reklamen imidlertid underkastet de samme basale kategoriseringer genremæssigt set, som alle andre tekster. Wells ${ }^{8}$ har argumenteret for en skelnen mellem lecture og drama som en grundlieggende måde, hvorpå TV-reklamer kan typificeres. I opstillingen af denne dichotomi bekymrer han sig ikke om to andre grundlæggende genreformater: det episke og det lyriske. Og selv om hans ærinde er et lidt andet, er han, så vidt jeg kan se, inde på et rigtigt spor med en sådan mere formel tilgangsvinkel, idet der dermed først og fremmest lægges vægt på de uudtalte forventninger, antagelser og underforståetheder, som er indbygget i en bestemt genre, dvs. det forhold, at en bestemt genre-form forudsætter en bestemt receptionsmodus. Man kan også kalde det de illokutionære aspekter ved genrefænomenet: på samme måde som et mentalt skema (scheme) eller en forståelsesramme (frame) angiver genren bestemte grænser for teksten, ligesom den indeholder basale direktiver med hensyn til tekst-læser relationen og med hensyn til, hvordan teksten skal forstås.

Hvad der derimod er problematisk ved Wells essay, er, at han på et andet niveau ikke opererer med reklamen som en genre, og hvad dette implicerer: at ligegyldigt hvor meget reklamen forsøger at gøre sig til 'drama', fiktion eller lignende, så vil den aldrig være i stand til at totalt at frigøre sig fra 1) dens referentielle bindinger til produkter og tjenesteydelser (i videste forstand), sådan som de erfares og opleves i virkeligheden, eller 2) publikums eller forbrugernes bevidsthed om, at reklame er kommunikation, som er styret af en bestemt hensigt. Skønt Benetton har forsøgt at overskride også disse grænser," og skønt megen postmoderne tænkning har påstået, at de forlængst er overskredet, er de stadig fuldt virksomme og formentlig formet af et stof, der er mere solidt end Berlin-muren.

Genre-begrebet som sådan er en omdiskuteret størrelse, bl.a. fordi det ikke er muligt at angive entydige bestemmelser i forbindelse med genrekategoriseringer: er de afledt af udsigelsen, er de afledt af signifikante træk ved indhold, tema eller struktur, eller er de afledt af ren og skær konvention/brug. ${ }^{10}$ I 
nærværende sammenhæng skal jeg ikke gå i dybden med disse problemer, ${ }^{11}$ men blot fastslå, at uanset disse problemstillinger ubetvivleligt omgærder begrebet, så er alle enige om, at det er et nødvendigt analytisk værktøj, på samme måde som genrebevidsthed generelt er nødvendig, når man ønsker et kommunikere. Og det hvadenten man arbejder inden for minimalistiske formater eller ej.

\section{Faktuel og fiktionel}

Set i forhold til mit begrænsede formål er det indtil videre tilstrækkeligt at basere en kategorisering på formelle træk, nemlig udsigelsen, hvilket stort set også er i overensstemmelse med Wells. Men mens modsætningen i følge Wells udgøres af drama overfor lecture, vil jeg hævde, at den grundlæggende modsætning består af faktuelle over fiktionelle henvendelsesformer i relation til publikum. Mens selve det at henvende sig, selve handlingen 'at kontakle' er mere eller mindre synlig eller hørbar i den faktuelle form, og mens den faktuelle form typisk implicerer en specifik reference, så søger den fiktive form først og fremmest at slettc ethvert spor pă del område, ligesom den er uspecifik.

På TV har den faktuelle form sin prototype og sine helt typiske udsigelseshicrarkier i TV-nyhederne: der er en studievært (presenter) med direkte kamerakontakt som et niveau; der er den anonyme speaker eller yoice-over, der taler og forklarer i forbindelse med et billedmateriale, som ruller hen over skærmen; der er reporteren ude i marken (stand-up) ligeledes med kamerakontakt; og der er interview-personen, som ikke tillades kamerakontakt, men som er kilde eller belæg og vidnesbyrd for, hvad der i øvrigt siges. Alle er de dele af et didaktisk og informativt varietélignende show, der befinder sig på forskellige udsigelsesniveauer og med forskellige autoritetsgrader. Og som det umiddelbart fremgår, er der formel overensstemmelse mellem TV-nyhedernes presenter og reklamens presenter, på samme måde som der er det mellem intcrviewpersonen og reklamens testimonial.

Den fiktive form på TV og i film har først og fremmest sin prototype i det fortællende drama, som er skruet sammen efter den klassiske analytiske montages principper, men også i den langt mindre narrativt organiserede og mere lyriske, visuelle montage, som imidlertid ikke cr sxrligt hyppigt forekommende.

Mens den faktuelle form er karakteriseret ved, at det er en stemme eller en stemme/et ansigt/en person, som kontrollerer og styrer begivenhederne bl.a. ved at indsætte illustrationer og billedmateriale i overensstemmelse med det 
sagte, og mens den også implicerer spørgsmål om autoritet, troværdighed, (mod)argumentation, er den fiktive form karakteriseret ved, at tingene her udspiller sig som en (som regel ukommenteret) kæde af begivenheder og handlinger (næsten som i det virkelige liv) eller en billedfølge, som uformidlet spiller ud til seerens egne evner for at fortolke og drage slutninger, ligesom den forudsætter seerens evne og lyst til at leve sig ind i og ville opleve en imaginær verden. I den illusionssammenhæng spiller diegesen den afgørende rolle, dvs. det forhold, at tilskueren kan blive ved med at opfatte sig som tilskuer og medvider og ikke som én, der bliver belært og talt direkte til. Med andre ord: ikke som én, der er i en kommunikationssituation.

\section{Faktuelle: voice-over, presenter, testimonial}

Set under udsigelsens rent formelle synsvinkel kan TV-reklamer eller TVspots med andre ord opdeles i to grundlaggende formater: a) fiktive og b) faktuelle. I de faktuelle ligger styringen på udsigelsens andet niveau. Enten i form af en bagvedliggende stemme (voice-over), som styrer og forankrer sekvensen, eller via en afbilledet person, som direkte henvender sig til skærmen en face (stand-up, presenter, anchor-person) eller via en interviewperson/anbefaler, som i visse sjældne tilfæelde kan tale direkte til kameraet, men oftest har rollen som tredje person, der i grader af profil beretter om sine oplevelser og giver sit besyv (testimonial). Voice-over'en kan selvsagt omformes i sang, ligesom den kan sættes på versefødder, og der kan være tale om forskellige grader af udveksling og samspil mellem, hvad stemmen siger, og hvad der vises. På samme måde kan man med udgangspunkt i presenter'en som format etablere et lille spil eller drama mellem udsigelsens andet og dens - ganske vist illusoriske - første niveau som i det følgende eksempel (fra april 1992), der metakommunikativt og humoristisk fremviser, hvordan også presenter'en er iscenesat.

En hurtigttalende og veloplagt smilende presenter/sælger med ansigt og pegefinger direkte mod skærmen fylder billedet. Lidt utydeligt kan man se, at baggrunden er udformet af store sorte og hvide cirkler i form af noget, der ligner en skydeskive. »Halløjsa venner. Så skal der sælges. Far her (tommelfingrene op) har fået til opgave at fortælle Jer ... « En stemme udefra afbryder: »Stop! Stop! Det dur ikke!«. Sælgeren trækkes brutalt ud af scenen af, hvad man må formode, er en instruktørarm. $\gg$ Kom her. Det er for kedeligt. Vi prøver noget andet«. Nu set i fugleperspektiv, men med samme baggrund som før (skydeskiven) trækker 
intruktøren fyren ind igen. Han er splitternøgen bortset fra sko og strømper. Forlegent dækker han skridtet med hænderne. »Stil dig her« siger instruktøren og peger på centrum i skiven. »Deroppe er kameraet (peger opad dvs. mod seeren). Og rul dig nu ud«, råber han, mens han forsvinder ud af billedet. Den generte presenter i bar figur: »HAL .. øjsa«. Instruktørens bryske stemme:« Den er lang...«. Presenter (langsomt og tøvende): »Den er $\emptyset \mathrm{h} \mathrm{l-lang} \mathrm{...} \emptyset \mathrm{h}$ r $\varnothing \mathrm{d}$ og blød indeni og med en lille smule guld på spidsen. Og să smager den godt «. Instruktøren: »Og vis os så, hvor lang den er«. Presenter'en vender sig måbende vantro mod instruktøren uden for scenen og siger stakåndet: »Skal jeg virkelig også vise den «. Instruktøren utålmodigt: »Jep. KOM så. KOM så!!«. Presenter'en adlyder og trækker produktet lynhurtigt ud af skødet, mens kameraet zoomer ind med close-up på Center Chokolade (rulle) og pay-off tekst, som instruktør stemmen også udtaler: »Center Chokolade. Ikke så kedelig, năr først du ruller den ud! «

I disse faktuelle formater, som eksemplet her ganske vist driver et humoristisk spil på at underminere og driver frem til et minidrama, styrer stemmens udsagn, og hvad der siges, begivenhedernes gang. Ligeledes er de karakteristiske ved den (tillempede) direkte henvendelsesform og (det fingercdc) spil på interpersonelle kommunikationsmåder. De søger at efterligne eller mime en slags (pseudo) interaktion med publikum (direktiver, fatisk kommunikation, deixis). Men først og sidst: formen hviler på autoritet og på troverdigheden i figuren og/eller stemmen og det udsagte, dvs. argumenter og modargumenter og deres relation og relevans i forhold til folks adfærd. I presenter formen er figurens evne til at etablere et foregivet (samtale)rum med seeren afgørende. På samme måde er det ikke hvilke som helst stemmer, som kan bruges i voice-over formatet. Nogle stemmetyper giver associationer i retning af det umiddelbart autoritative og troværdige.

\section{Fiktive: Drama og montage}

I de fiktivt orienterede former holdes udsigelsens tredje niveau som regel helt frem til signaturlinjen, hvor produkt/mærkenavn og eventuelt slogan dukker op som afsluttende pointe og punktum. Dramaet eller det visuelle forl $\emptyset \mathrm{b}$, der er anlagt efter en narrativ struktur, udgør en dominerende form $\mathrm{i}$ medierne. Her er den autoritative, belærende, fortolkende og forklarende stemme stort set fraværende, og der er intet forsøg på at spille op til direkte kommunikation med secren som et »du«. Seeren har kun det viste, det udspillede forløb at for- 
holde sig til. For at kunne gøre det må spottet fra første øjeblik gribe fat i en genkendelig situation, scene og milj $\varnothing$ eller en veletableret genre og dens signaler. Disse velbekendtheder gør, at seeren hurtigt kan slutte sig til, hvilken retning forløbet normalt vil tage, hvilket univers der er tale om, og hvilke myter og underforståetheder, der er på færde. Typisk er udgangspunktet en genkendelig situation i et dagligdags univers: familie- eller vennesamvær, køkken, spisesituation, sammentræffet på gaden, sammenstødet, arbejdsstedet, køreturen, butikken. Som amerikanerne siger på reklamens område: man skærer en skive ud af livet (slice-of-life). Men brug af velkendte skuespillere (komikere) i sketches er også typisk: to faste figurer i et fast sceneri og en dialog, som har vitsens form. Disse minidramaer er underkastet de samme krav til troværdighed, som generelt gør sig gældende for fiktive handlingsgange, og som normalt sammenfattes i begrebet verisimilitude. De er styret af konventioner og regler fra dramaets verden. Konventionerne for, hvordan man fortæller i billeder, og hvordan man strukturerer et drama/en fortælling i levende billeder.

En helt anden form for visuelt konstrukt har man i (parallel) montagen, som ikke er opbygget over en bestemt handlingsgang frem mod en pointe (plot) og som heller ikke udtrykker nogen anden handlingsmæssig progression end den, som håndfast tilvejebringes eller konstrueres igennem de visuelle elementers flow. Det fremaddrivende er her ikke et samlet forløb i et handlingsplan med bestemte aktører, dialog, mimetisk gengivelse af situation tid/rum, men sammenklipning, der er styret af gentagelse, kontrast, parallel mellem billedelementer/scener og som regel underlagt en bestemt rytme og et musikalsk forløb som underliggende styrende faktor. Sammenkædning og kohærens er ikke et resultat af normale styrende kræfter og logikker såsom årsag-virkning eller tidrum, men er styret af en associativ og lyrisk organisering af stoffet. Det er dermed overvejende et paradigmatisk styret forløb i modsætning til det syntagmatisk styrede forløb, som gør sig gældende i forbindelse med det fortællende format. Montage-formatet betoner stemning, og slutninger om forløbet kan kun drages ud fra de strukturer eller mønstre, som gentagelser og paralleller danner via lighed, forskel, modsætning i sammenstødene mellem klippene. Fragmenter fra fortællende forl øb kan således indgå, men kun for at opbygge en forestilling om en særlig atmosfære eller mental tilstand eller for at karakterisere bestemte tilværelsesaspekter og fænomener.

For både dramas og montages vedkommende spiller spørgsmålet om relevans en afgørende rolle. Dvs. relevans ikke blot set i forhold til publikums relevansstrukturer generelt, men også relevans set i forhold til produktkategori og mærke og oplevelsen af disse. Især i forbindelse med de fiktive former er det afgørende, at de formår at opbygge en betydningsmæssig nærhed og tæt 
pointe i forhold til mærke/produkt/brugsaspekter, netop fordi de opererer med en indirekte fremstilling af budskabet.

De kategorier, som kan sættes i værk på materialet (og der ses i behandlingen bort fra spots af udenlandsk oprindelse), er dermed på den ene side: den faktuelle eller didaktiske form med følgende underliggende former: voiceover, presenterlannouncer, anbefaler/testimonial. Og på den anden side: fiktiv form med underliggende former som drama og montage.

\section{Applicering af kategorierne på materialet}

En kategorisering af de danske TV-spots efter disse kriterier giver følgende billede. Og vær opmærksom på: 1) At udenlandske spots er blevet udskilt som en kategori for sig, ligesom de ikke er blevet gjort til genstand for yderligere kategorisering. Det gelder, hvad enten spottene er versionerede eller ikke. 2) At specificeringen $\mathrm{i}$ danske henholdsvis udenlandske spots kan være omgærdet med en vis usikkerhed på grund af mangelfulde oplysninger i TV2 Reklames registreringer (især før 93).

\begin{tabular}{l|c|cccc|cc}
\hline & Udenl. & \multicolumn{5}{|c}{ Danske } \\
\hline & & \multicolumn{4}{|c|}{ Faktuel } & \multicolumn{2}{c}{ Fiktionel } \\
\hline & & v.o. & v.o+ & pres. & test. & drama monta. \\
\hline & & & & & & & \\
Apr. 89 & 24,2 & 46,2 & 0 & 8,0 & 2,2 & 15,0 & 4,4 \\
Apr. 92 & 21,6 & 43,6 & 7,5 & 11,7 & 0 & 13,6 & 1,8 \\
Apr. 94 & 34,5 & 30,8 & 8 & 3,7 & 3,7 & 14,7 & 4,6 \\
\hline
\end{tabular}

(N=Apr. 1989:92;Apr. 1992:213;Apr. 1994:210)

Tallene angiver klart, at den faktuelle form, herunder især voice-over formen, er dominerende (om opdelingen af voice-over i v.o. og v.o.t sc nærmere nedenfor). Den faktuelle form og voice-over'ens dominans ville være endnu mere fremherskende, hvis de versionerede spots blev inddraget, eftersom versionering først og fremmest består i en æundring af voice-over. Det er måske bemærkelsesværdigt, at en af reklamens gamle former, testimonial'en, ikke spiller en større rolle, og at spots i presenter form - efter noget der ligner en kulmination i 1992 - er gået voldsomt tilbage. Hvad man imidlertid er nødt til at være opmærksom på, er følgende særlige forhold: mens ultrakorte v.o.-spots af maksimalt 10 sekunders varighed og stort set bestående af en jingle, en stemme, der tilsat illustrationer annoncerende produkt, pris og sted for super- 
markedskæder og andre detailhandelskæder, ikke spillede nogen rolle i 1989 , så gjorde de det til gengæld i 1992 og 1994. I begge de udvalgte måneder udgjorde de næsten halvdelen af v.o.'erne. Set i forhold til det samlede materiale udgjorde de 24\% (1992), henholdsvis 16\% (1994).

For at yde materialet fuld retfærdighed er det på samme måde nødvendigt at arbejde mere differentieret inden for voice-over formen end oprindeligt antaget. Det hænger sammen med, at nogle af v.o.'erne (efter 1989) viste sig at være af en helt anden støbning end gennemsnittet. Det er grunden til, at jeg har fundet det af afgørende betydning at indføre et skel mellem på den ene side den typiske eller gennemsnitlige voice-over (v.o.), som netop er typisk ved, at der er tale om en større eller mindre grad af redundans mellem sagt og vist først og fremmest ved, at billedsiden stort set fungerer som illustration af det sagte, og så på den anden side den atypiske voice-over (v.o.+), hvor det sagte og det viste indgår i mere intrikate spændings- og udvekslingsforhold, og hvor hensigten i højere grad er at spille op til publikums egen slutningsevne. Af samme grund skal jeg senere nedenfor bevæge mig ind i en mere kvalitativ behandling af v.o.-formen og give en mere nuanceret bestemmelse af dens forskellige potentialer. Dette hænger også sammen med, at det er inden for denne kategori, man finder de mest interessante udviklinger på den kreative front, og at behovet for en særlig kategorisering på dette felt så at sige dukker op af materialet.

Med hensyn til udviklinger i øvrigt angiver den kvantitative opgørelse ikke afgørende ændringer, for så vidt angår forholdet mellem f.eks. de faktuelle former overfor de fiktive. Billedet er nogenlunde stabilt. Den faktuelle form med v.o.'en som særligt fremherskende form er den klart dominerende, om end det er muligt at se ' 94 som et tegn på, at den faktuelle form måske er på retur efter at have kulmineret i ' 92 , og den fiktive form omvendt er på fremmarch efter at have dykket i '92.

Subformater som testimonial og montage er på ingen måde overforbrugte. Med hensyn til presenter-formatet ser man en vækst og så et fald. Dette hænger formentlig sammen med, at det, som man kunne kalde 'Lars Larsen-effekten', er aftagende. Lars Larsen/Jysk Sengetøjslager var som bekendt ${ }^{12}$ den første, der forstod at udnytte dette format via 10-sekunders spot, som også indeholdt et lille uforudsigeligt humoristisk element, og gjorde det i et sådant omfang, at han blev verdensberømt i Danmark i løbet af det første halve år, der overhovedet blev sendt TV-reklame (efteråret 1988). Mange fors $\emptyset$ gte at gøre ham kunsten efter ikke mindst på grund af de lave produktionsomkostninger (7-8 forskellige spots $=100.000 \mathrm{kr}$.). Hvis man kigger nøjere på materialet fra april 1992, er der indikatorer på, at presenter-formatets kulminationen på dette tidspunkt også samtidig er udtryk for, at det er ved at være slidt ned. Parodier 
og travestier (om ikke så radikale som det tidligere eksempel med Center Chokolade) begynder at gøre sig gældende. Dette kunne tyde på, at en cyklus inden for dette format er ved at være tilendebragt; at det er blevet vanskeligt at skabe nye, troværdige og markante TV-spots i formatet, hvorfor der spilles på selve formatets form: det gøres til indhold.

\section{Det danske, didaktiske TV-reklame spot. En forel $\phi b i g$ konklusion}

Det er en almindelig fordom, at billedmedierne, herunder TV, skulle være specielt velegnede til at spille pă publikums følelser set i forhold til de trykte medier. At med andre ord selve visualiteten og den visuelle oplevelsesmåde og det 'forførende' heri skulle gøre, at stemninger, følelser, emotionalitet, æstetik omkring fænomener (og produkter) bedre lader sig formidle og inducere via TV end via de trykte medier. De trykte medier skulle på deres side være bedre til at informere, belære, give argumenter mv. Hvordan det rent faktisk forholder sig, skal jeg ikke rode mig ud i en læengere diskussion af her. Men set i forhold til standpunkter af denne type er det i hvert fald markant, at dansk TV-reklame i meget høj grad ser ud til at være belærende i sin fremherskende grundform. Selv når man fraregner den meget store bunke af reklamespots, som er signeret af de store detailhandelskæder på dagligvareområdet (FDB (Brugsen, Kvickly, OBS), Bilka, Føtex, Spar, Davli, Favør), og som i det store og hele består af redundans mellem en afbilledet vare, en pris og en voice-over (eller præsenter), er mindst $50 \%$ af spottene af den didaktiske type, der overvejende anslår en faktuel kode og en direkte rettethed mod publikum enten via voiceover'ens verbale eller en presenters (en på mærkets vegne talende) visuelle henvendelse. Under en tredjedel er med andre ord spots, som anslår en fiktionsform, eller det som Wells ville betegne som drama, der spiller op til publikums egen fortolkningsevne.

Dette kunne indikere, at TV-reklame i Danmark stort set er en temmelig rationel og jordnæer affære uden de store fantasifulde armsving, ligesom det kunne indikere, at danske annoncører finder, at de didaktiske formater er at foretrække, dels fordi de er relativt billige at producere, dels fordi budskabet kan fremstilles klart og utvetydigt. Ligeledes kunne det indikere, at der er tale om generel skepsis med hensyn til at udvikle de mere æstetiske sider af TV-reklamen. Der er ikke meget der tyder på, at den tendens til udvikling af netop reklamens æstetiske side, som Kloepfer \& Landbeck ${ }^{13}$ mener at kunne påvise igennem nogle meget omfattende undersøgelser af europæisk TV-reklame i 80erne, skulle gøre sig gældende i Danmark. Men måske bliver billedet mere 
differentieret, hvis vi går lidt mere i dybden med den mest fremherskende form i dansk TV-reklame, voice-over formatet.

\section{Voice-over-formen kvalitativt betragtet}

Som den kvantitative undersøgelse har vist, er langt størstedelen af de TV2 reklamespots, benytter en faktuel fremstillingsform, karakteristiske ved at være styret af en voice-over. Dvs. at et talt forløb repræsenteret af en stemme offscreen udgør den afgørende faktor i styringen af spottets forl $\varnothing \mathrm{b}$. Forholdet mellem tale og billede kan så være præget af forskellige grader af forankring (ancrage) henholdsvis afløsning (relais). ${ }^{14}$ Det visuelle har ikke nødvendigvis kun karakter af at være illustration. Der kan være tale om en lang række forskellige mere eller mindre sofistikerede samspil.

Den mindst sofistikerede og mest simple form findes selvsagt, når der er tale om en ren og skær illustration forankret i talen, således at der næsten er total redundans imellem det sagte og det viste. Som i følgende spot for Merrild Kaffe (april 1992):

(billede) 'Røde Merrild kaffeposer i et varmt skinnende lys' (v.o. der' akkompagneres hele vejen igennem af en hurtigtløbende klaveretude) »Klip toppen af Merrild Kaffe« (bill.) 'hånd iført saks klipper toppen af Merrild kaffepose' (pianoet standser momentant, mens dette gentages 3 gange med højtlydende rytmiske sakseklip) (v.o.) »Og få krus« (bill.) 'krus med kaffe' (v.o.) »eller kaffekopper« (bill.) 'kopper med kaffe' (v.o.) »Eller kontanter« (bill.) '20-kroner linet op i en håndflade' (v.o.) »Hvis du ønsker kopper eller krus, să send en check« (bill.) 'check' (v.o.) »Send check og toppe til Merrild« (bill.) 'postkasse' osv. osv.

Bortset fra den rytmiske sakselyd, som er sat ind i den hurtigtløbende etude, er spottet præget af total spændingsløshed mellem stemmens udsagn og billedsiden, det sagte og det viste (medmindre man da ikke ved, hvad det vil sige, at klippe toppen af en pose kaffe osv.). Den visuelle side kunne i princippet undværes, når bortses fra præsentationsværdien angående emballagen og kopper og krus. Derimod var det modsatte nok ikke muligt, hvad der hænger sammen med talens direktiver (»klip«, »send «).

Det autoritative $\mathrm{i}$ formen kommer tydeligt frem, når det afbillede skal indgå som retorisk illustrativt argument/dokument for talen. Mobil Oil viser to identisk udseende løbere på et løbebånd. Voice-over'ens påstand er så en påstand om almindelig olie overfor Mobil, mens den ene løber transformeres til en 
miniput, der skal løbe ti gange så stærkt, mens den anden holder størrelsen og takten. Det visuelle udgør her en lignelse, der skal konkretisere begrebet om oliens egenskab og ydeevne.

Graden af redundans kan mindskes på forskellig vis. Først og fremmest ved at forskyde den hen mod det tidspunkt, hvor signaturen kommer ind. Dermed făr det visuelle forløb lov til at fremstå i dets egen ret $i$ et kort tidsrum, før talen griber forankrende eller på anden måde styrende ind. På den măde opnås en vis initiel spænding eller stemning før forløbets betydning 'stemples' eller ‘oversæettes'. Et eksempel fra Kelloggs Cornflakes (april 1992) kan vise det og samtidig også vise en manglende bevidsthed om at mindske redundansforholdet på en anden led:

(bill.) 'Scenen er et køkken. En cirka 6-årig pige sidder og spiser cornflakes. Faren (formentlig) kommer i billedet. Stående tager han en portion. Efter første mundfuld lukker han øjnene med et inderligt nydende og smilende ansigtsudtryk' (v.o.) »Hvis du vil se, hvor godt Kelloggs smager, behøver du blot at lukke øjnene«.

Voice-over'en er her skudt helt hen til signaturlinjen og er næsten identisk med den som en verbal pointering af forløbet i scenen. Samtidig er der klar redundans mellem det visuelle og det verbale (pointen med at lukke $\varnothing j n e n e$ ), hvor en mindskelse af redundansen og en minimal øgning af spændingen ville bestå i f.eks. enten: »Hvis du vil se, hvor godt Kelloggs smager, så skal du blot åbne $\emptyset$ rerne« eller »Hvis du vil høre, hvor godt Kelloggs smager, behøver du blot lukke øjnene«.

En anden, men mindre udbredt mulighed er at gøre spottet som helhed identisk med signaturlinjen. Eva Trio (april 1992) viser produkterne drejende på en mørk baggrund med en voice-over, der fastslår: »Formgivet -- formfuldendt - en livsform fra Eva Trio«. Her skaber allitterationen, sætningsfragmenterne og gentagelsen (af 'form') en vis suggestiv effekt i forbindelse med den visuelle enkelhed, der også betoner form. Paradokset er selvsagt, at billedsiden hævder, at formen taler for sig selv. Og det făr den ikke lov til. Og det er ganske karakteristisk, på samme måde som Eva Trio er karakteristisk for en genkommende form inden for produktpræsentation.

Egentlige afløsende og nuanceforskydende betydningsforhold, som skaber et spil mellem det visuelle og det verbale, kan etableres på den meget simple måde, at billedsiden afløser og kompletterer det verbale forløb. F.eks. i form af (v.o.) »Hvis du har sådan én« (billede af 'sådan en' = en film) (v.o.) »... så har vi sădan en « (billede af pose til at sende filmen i) osv. Billedsiden făr med andre ord en ostensivt konkretiserende og specificerende funktion, der står i 
modsætning til den ubestemthed, som styrer verbalsiden. Forbilledet er rebussen.

En afløsende og nuanceforskydende form, hvor samspillet ikke i samme omfang er fastlagt som en slavisk kompletterende udfyldning af en sætningsstruktur, men også preget af henvisning til, hvad der sker på billedsiden, optræder, hvor v.o. kommenterer en scene/et set-up. F.eks. (Viborg Dæk september 1992):

(v.o.): »Her er en mand« (bill.) 'Hvinende dæklyd og ind i billedet ryger en scene med mand, der sidder på gulvet $\mathrm{i}$ et bart setting og fingerer, at han styrer en bil med et imaginært rat omgivet af 4 dæk på højkant' (v.o.) »Han er glad« (bill./scenen) 'Manden vinker og smiler' (v.o.): »Han har lige købt 4 Viborg dæk for $995 \mathrm{kd}$. i Hjulcentret«.

Billedsiden er ganske vist præget af redundans, hvad angår forløbets eneste udtryksfulde handlingselement (»han er glad « = 'vinker og smiler'). Derimod giver selve scenen, som det verbale forløb henviser til, en speciel udfyldning af historien om den glade mand i og med, at han sidder og illuderer eller leger 'at køre bil' omgivet af 4 opretstående dæk, der ud over mandens aktiviteter er de metonymiske repræsentanter for 'bil'. Manden er dermed ikke blot glad, han er en lallende glad/gal mand, der på infantil vis leger bilist. Den bevidste naivisme, der gennemstrømmer både v.o. og scene, skaber dermed en stilistisk helhed. Men det er den afbillede scenes særlige karakter af ville 'sige' bilkørsel, men udelade alt andet end aktøren og dækkene og dermed skabe en overtydelig redundans, der kalder på smilebåndene. Også fordi formen alluderer til nogle af de allerførste sætninger, der står i en læsebog (henvisninger mellem tekst og billede via det påpegende 'her') og enkelheden i de konstaterende sætninger, som bygger pointen op uden eksplicitte årsagsforklaringer. Spillet på en forudbekendt udtryksform kombineret med scenens markerede halvgroteske karakter af udeladelse (af bilen) og overdrivelse (af dækkenes rolle) angiver humoren. Den særlige sceniske udfyldelse af det verbale udsagn giver dermed spottet dets spænding i spillet mellem udtryksniveauerne, men også dets helt specielle naivt-ironiske stil.

Dette ironiske afløsnings- eller udvekslingsforhold, der giver historien spænding i ‘hullerne' eller de indholdsmæssige niveauforskelle mellem, hvad der vises, og hvad der siges, kan udvikles yderligere f.eks. i form af underdrivelse. Samsonite har en typisk engelsk sådan (april 1992).

(v.o.) »When you travel a lot, you need to take precautions« (bill.) Mand i safariudstyr og kuffert, der transporterer sig på krokodilleryg ad jungle- 
flod', (klip) (bill.) 'Han kastes af, og den angribende krokodilles opspærrede gab neutraliseres via kufferten, som dermed på dramatisk vis udstilles mellem dens kæber i sidste billede' (v.o.) »See what I mean?«.

Her er det dels spændingen mellem »travel a lot « og den noget specielle rejsende figur og hans livsfarlige transportmiddel, dels spændingen mellem »take precautions « og kuffertens sluttelige funktion som effektivt forsvarsmiddel, som danner hullerne og de niveauforskelle, som er humorens. Det er den semantiske afstand mellem begrebet ('travel') i læresætningens form og den illustrerende konkretiserende udfyldning, som skaber spændingen sammenhængende med den manglende benævnelse af, at det er kufferten, det drejer sig om. Handlingsforløbet på billedsiden har her selvstændigt bærende værdi, men den metakommunikative og underspillende ironi, det vitsagtige kan lige præcis kun komme frem ved hjælp af talen og står i afbalanceret modsætning til grotesken med manden på krokodillen.

Forholdet mellem voice-over og billedside kan dermed være ret forskelligt. Der kan være tale om ren og skær illustrerende sammesigen, om simpel forankring, om postuleret metaforisk illustration, om afløsning, om ironi mellem det sagte og det viste. Voice-over'en tilfører først og fremmest en verbal spilmulighed, som er mest effektiv, når den står i et eller andet kontrapunktisk, metakommunikativt, nuancerende eller uddybende forhold til billedsiden og dens forl $\emptyset$ b. Billedsiden kan dermed tillade sig lidt af hvert med hensyn til overdrivelser, grotesker mv. Talens styrende effekt skal nok bringe balance i tingene. Den virker under alle omstændigheder forankrende og styrende på forløbet, som ikke făr lov til selvstændigt at styre betydningsdannelsen. Den er i sidste instans autoriteten. Og v.o.-TV-spots ved godt, at de kan have et problem med denne bestandige stemme og dens tilbud, opfordringer og anbefalinger. Undertiden går det så vidt, at de føler, at det er på tide at fremvise en modstræbende forbruger, der ligefrem snerrer ad den, som i det følgende cksempel (fra januar 1993):

Den noget matroneagtige Fru Larsen (som hun omtaler sig selv) ses i nærbillede. Med sit sure ansigt og sin skærebrænderstemme er hun igang med at harcelere over, hvordan »Fru Larsen« må »mølle rundt « fra Herodes til Pilatus for fă ugens tilbud. En voice-over bryder ind i form af en friskfyragtig stemme, mens Fru Larsen står i samme fortørnede positur: "Nej, nej, nej. Kom blot ind i Favør. Vi har alle de gode tilbud (nævner en vare og en pris), wagga, wagga, WAGGA. Er der noget de søger, så kom ind i Favør«. Fru Larsen făr det sidste ord med et surt vrængende: »Waagga - Waagga - Waagga . 
Autoritetsaspektet og talens påtrængende forstyrrelse af det visuelle kan imidlertid umiddelbart neddæmpes og omformes, ligesom man kan neutralisere det aspekt, der er forbundet med enhver stemme: at den altid uundgåeligt bærer præg af en person eller persontype. Det kan simpelthen gøres ved, at man lader det sproglige indgå som visuelt element: teksten og ordene trykkes ud på skærmen. På denne måde kan ord og sætninger også blive visuelt aktive handlingselementer.

Den indlagte bagvedliggende stemme, hvis fremfører ikke kan ses, kan dermed antage forskellige udtryksformer. Normalt garanterer den en slags 'sagligt' (jeg)-du forhold i kommunikationen, der så at sige holder et tredje (visuelt, illustrerende) forhold op for seeren, peger på det, kommenterer det. Men den kan også have en bevidst desorienterende effekt m.h.t. hvilket 'jeg', der taler i forhold til, hvad der sker på billedsiden. F.eks. hvis dette 'jeg' faktisk illuderer at udtale sig som sådant i form af emotive sprogfunktioner (den talende er en del af det, der sker på billedsiden), og dette 'jeg' normalt er umælende (et dyr, en ting). Dermed kommer der en spænding ind mellem den bagvedliggende stemme og dens rum og det visuelle rum.

Men voice-over'en kan også bruges som en tvetydig henvendelse (typisk i form af spørgsmål/retorisk spørgsmål), som i princippet både er rettet mod seeren og personer i det viste. F.eks. (Bikuben april 1992):

(v.o.) »Hvem hjalp dig, da du skulle have nyt lån til ombygning af huset?«(bill.) 'Kvinde på vej ned ad trappe og sluttelig med direkte kamerahenvendelse, der siger: »Bikubens boligrådgiver« (herefter et antal varierede spørgsmål-svar gentagelser).

Eller (Netto april 1992):

(v.o. og tekst der printes ud på skærmen): »Mangler du noget i NETTO? « (bill.) Enquéte i forretning og mand på indkøb, der siger: »Det sku' da lige være no'et fersk kød«. (herefter en række parallelle gentagelser) (v.o.) »Nu er der frisk kød at få i din NETTO «.

Hermed rendyrkes et træk ved den voice-over styrede form: det gennemgående træk af stemmens direkte betoning af 2. person ('du'). Men hermed ses det også, hvor rige spillemulighederne er ved hjælp af voice-over'en. Den kan indgå i spil med selve det visuelle forløb og være i direkte udveksling med det sceniske; den kan spille ud mod seeren ved at henvende sig til seeren som eksplicit 'du'; den kan være en neutral, en autoritativ, en ironisk osv. kommentar, der ledsager og guider seeren til det viste, og hvordan det skal forstås; den kan 
være et eksplicit 'jeg', der erindringsmæssigt eller som indre stemme fortæller med illustration. Den har kort og godt alle muligheder for at spille på ikke blot sprogets funktioner (ekspressive, konative, referenticlle, fatiske, metakommunikative, poetiske $)^{15}$ og de forskellige udsigelsesniveauer, men også udbygge og fortætte dette spil via billedsiden. Så der er ikke noget mærkeligt i, at formen spiller en fremtrædende rolle. Den giver simpelthen mulighed for at udtrykke et budskab kort, koncentreret og varieret i et omfang, som ingen anden form formår. Den passer perfekt til TV-spottets påtvungne krav om minimalisme og giver mulighed for at udnytte de minimale rammer optimalt. Og ydermere: den ligger i nydelig forlængclse af de trykte mediers og radioens kommunikationsmåder.

Men ligegyldigt hvordan man i denne form fors $\emptyset g e r$ at vende og dreje tingene, så har den i hvert fald svært ved at appellere til indlevelse. Den bærer præg af den autoritative forfatter og har $\mathrm{i}$ det hele taget æstetisk baggrund $\mathrm{i}$ 1700-tallets moralsk-didaktiske fortælling med illustrative belæringer og eksempler, men også med fortællerironi.

I voice-over formatet kan man sige, at reklamens grundlæggende bekymring kommer til udtryk: Frygten for at budskabet ikke kan blive tydeligt og manifest nok via det visuelle, at det f.eks. kan misforstås. Det bevirker ofte, at voice-over'en kommer til at overtydeligg $ø$ re betydningen og fremtræder mere påtræengende end nødvendigt med sit diktat til secren om, hvordan det sete skal forstås.

Mere pragmatiske forklaringer på dette æstetiske 'misbrug' af voice-over'en findes i det ganske simple forhold, at en god del af TV-spottene er versioneringer. I den sammenhæng er det ulige lettere at lægge en stemme ind over billederne, end at forlade sig på eftersynkronisering. En anden pragmatisk forklaring hænger sammen med, at en god del af seerne ikke ser, mens der er reklamer, men nok hører. Endelig for det tredje kan der være tale om, at TVspottet skal virke sammen med radio-reklame.

Men dette er ikke hele sandheden. Det er evident, at formen ikke først og fremmest lægger op til indlevelse, og at en af tormens mere manifeste konsekvenser er, at billedsiden - som illustration - er holdt i en arms cller en pegefingers længde mellem fortælleren og seeren. Men dette betyder på ingen måde, at formen ikke kan spille op til seernes egen slutningsevne og aktive konstruktion af betydning. Publikums medleven og medviden kan inddrages også i voice-over formen. Det sker i givet fald blot ad andre veje. Og langs disse veje optager afdelingerne for det humoristiske og vitsagtige, det ironiske og tvetydige i henvendelsesformen, det travesterende, parodierende og groteske en god del af pladsen. 


\section{Konklusion. TV-reklamens minimalismer i programperspektiv}

TV-reklamen er formentlig hverken værre eller bedre end gennemsnittet af TV's programmer i henseende til, hvordan mediet udnyttes: tale og ord, synlige og usynlige snakkehoveder er de dominerende og styrende størrelser. Det at levere budskabet eller fortællingen via det visuelle er på trods af mediets muligheder ikke ligefrem fremherskende, og den gennemsnitlige tillid til publikums egne slutningsevner er lav. Det er mere undtagelsen end reglen, at publikum selv inviteres til at være medbyggere på betydningen og budskabet. Det omvendte ville formentlig gøre sig gældende, hvis man flyttede over i en anden mediekontekst. Dvs. hvis det ikke var TV-reklame, men biografreklame, som det handlede om. ${ }^{16}$

At TV generelt klynger sig til tale, hænger selvsagt sammen med, at mediet i høj grad er vokset ud af radio og radioinstitutioner, ligesom det hænger sammen med det generelle vilkår, som gælder en række af de massemedier, der indgår i dagligdagens rutiner og udg ør en del af hverdagslivets faste ritualer: tale og ord er stadigvæk den hurtigste, billigste og mest præcise måde at levere informationer på. Udgifterne til programmer, der er baseret på tale er almindeligvis inkommensurable med dem, som er baseret på en fremstilling, som først og fremmest udnytter de visuelle muligheder.

Gennemsnittet af TV-reklame har - i lighed med TV's programmer generelt - en tiltro til, at kommunikation drejer sig om, at få tingene skåret ud i tale, sådan at alting gennemtygges godt og grundigt, og sådan at publikum ikke opfordres til selv at arbejde med betydningen. Man arbejder dermed med et temmeligt restringeret begreb om kommunikation, som kun i meget ringe grad holder sig for øje, at noget af det grundlæggende i forbindelse med kommunikation også drejer sig om at invitere sit publikum ind til en fælles oplevelse og give det muligheden for aktivt at dele og blive delagtigt i denne oplevelse ved at give det et mentalt spillerum i forhold til det viste og i forholdet mellem sagt og vist.

Interviewundersøgelser, der er gennemf $\varnothing r t$ på europæiske forbrugere, ${ }^{17} \mathrm{og}$ som sammenligner dem med henblik på forskelligheder, viser ganske klart, at danske forbrugere er nogle af de (i dette sprog) mest rationelt og kontant tænkende i forhold til forbrug. Den fremherskende form i dansk TV-reklame synes at bekræfte dette billede.

Den rstetiske grundform i dansk TV-reklame er først og fremmest faktuel og didaktisk. Det fremgår af den rolle, som voice-over formatet spiller - bakket op af andre faktuelle formater. Det er vigtigt, at budskabet kommer hørbart og relativt entydigt igennem som klartekst. Men som det også er vist, behøver 
denne præference for voice-over'ens fortrinligheder m.h.t. klartekst ikke at betyde, at formen som sådan slct og ret er fantasiløs eller nødvendigvis betinger, at publikum ikke skulle kunne inddrages som aktive medspillere. Tværtimod. De kan i denne form blot blive det på en anden vis: igennem spillerummet mellem sagt og vist og igennem sammenstød i det hele tagel mellem udtrykssystemerne og udtryksniveauerne. Ligeledes er det ganske klart, at denne form giver de største variationsmuligheder og frihedsgrader æstetisk set.

Endvidere skal man - $i$ hvert fald set $i$ forhold til et publikum, der er præget af en overvejende 'rationel' forbrugeradfærd - ikke se bort fra de umiddelbare fordele, som denne form besidder set i perspektivet af et elementært spørgsmål om troverdighed. I modsætning til en drama-form er de faktuelle former mere i overensstemmelse med ikke blot det referentielle aspekt, men ogsả med de basale imperativer og implikationer, som fremgår af den kommunikative hensigt: på kalkuleret vis at skabe opmærksomhed om et produkt eller mærke. Den lover ikke noget andet igennem selve udtryksmåden, mens et TV-spot $\mathrm{i}$ drama-form er konfronteret med et problem, dels med hensyn til graden af relevans mellem den fiktive fortælling og et spccifikt produkt, dels med et publikum, hvis holdning lynhurtigt kan omformes til et »mann merkt die Absicht und wird verstimmt

Så endskønt man kan have de bedste hensigter med at advokere for drannaform overfor de didaktiske formater, ${ }^{18}$ og endskønt de fiktive formater umiddelbart har den fordel, at de i højere grad appellerer til og inddrager publikums egen medleven, aktive betydningsdannelse og tilegnelse ved netop ikke at fiksere publikum i rollen som »talt til«, så er der intet belæg for at foretrække de fiktive fremstillingsformer på konto af, at de skulle være den eneste og bedste vej til at skabe et dynamisk udvekslingsforhold til publikum. Når det drejer sig om en TV-reklame, som er underlagt minimalismens fordringer, kan de 'fremmedgørende' spil indenfor alle trin af udtrykssystemet og på sammenstødene i selve udtrykssystemet være mindst ligeså effektive. Og det er ofte lattcr, der produceres i den sammenhæng.

Men bortset fra denne humoristiske og skæve form (og dens variant i form af lune), som generelt spiller en stor rolle i dansk reklame (også i dens fiktive former jf.. Tuborg Squash), så er det karaktcristiske og udbredte i TV-spottets verden, at den belærende, appellerende, opfordrende ( $\mathrm{g}$ ofte højtråbende) tale fungerer som den krykke, der skal holde resten oppe og ofte gør det nok så krampagtigt, dvs. ude af balance med det oplevelses- og stemningsindhold, som opbygges på billedsiden og uden tro på hverken publikum eller det dictum, som reklamen ellers også har gjort til sit: »Don't tell it. Show it «. 


\section{Noter}

1. Det følgende udspringer af forskningsprojektet »TV's æstetik «, nærmere bestemt delprojektet TV-reklamens æstetik. Hensigten i dette projekt er at undersøge TVspot reklamen som en art programmateriale og som en særskilt genre. Og især at fokusere på de æstetiske problemer, som gør sig gældende i denne særlige kortform anskuet som TV-programmer i lilleputudgaver. Hensigten er således ikke at efterspore effekter i forhold til publikum eller målgrupper, at anskue brugen af spots i kampagnesammenhæng eller at bedømme TV-spots som et element i en specifik markedsføringsstrategi. Udgangspunktet er, at TV-spots i lighed med ethvert andet tekstligt, audiovisuelt og kulturelt fænomen danner en egen særlig verden med sine egne kategorier, standarder og æestetiske problemer, og at genren udvikles i kraft af en dynamik, som også hænger sammen med selve genren.

Set fra et publikumssynpunkt er det dermed først og fremmest den dimension ved fænomenet, som har at gøre med, at publikum bruger TV-spots på andre måder end den i streng forstand intenderede. Publikum bruger bl.a. også TV-spots som små underholdende miniprogrammer, ligesom publikum også bedømmer dem ud fra deres æstetiske og underholdningsmæssige værdi.

TV-spottene udgør selvsagt ikke på nogen måde en isoleret egenverden. De er om noget dybt forankrede i intertekstualitet og står i en bestandig udveksling med andre genrer, med aktuelle problemstillinger, ligeså vel som de har del i sâvel konkrete som generelle problemer i forbindelse med information og kommunikation.

2. Jf. J. Stigel: »Det vigtigste er som regel det der ikke er der. Om kulturproduktion, reklame og propaganda«, in: J.F. Jensen et. al. (eds.): Reklame-Kultur, Aalborg 1993.

3. Om disse cyklusser og formater se f.eks. W. Leiss et. al. Social Communication in Advertising: Persons, Products and Images of Well-Being, Toronto 1986.

4. Om æstetiske kortformer se J. Stigel: »Er skriften til at få i tale«, in: H. Alrø og M. Kristiansen (eds.): Personlig kommunikation og formidling, Aalborg 1993.

5. En undersøgelse af både egenreklame og spotreklame på TV2 og TV3 er foretaget i C. Jantzen og J. Stigel: Reklamen i dansk landsdakkende tv. København 1995.

6. F.eks. A. Book og N. Cary: The Television Commercial, Chicago 1970, R. Hilliard: Writing for TV and Radio, N.Y. 1976, I. Hefzallah og P. Maloney Hefzallah: »Are there only Six Kinds of TV Commercials? «, in: Journal of Advertising Research, vol. 19 No. 4,1979.

7. Jf. G. Dyer: Advertising as Communication, London 1982.

8. W. D. Wells: »Lectures and Dramas«, in: Cafferata og Tybout (eds.): Cognitive and Affective responses to Advertising, Mass./Toronto 1989.

9. Jf. J. Stigel: Mellem astetik og kommunikation. Arbejdspapirer fra TV's astetik, Århus 1995.

10. Jf. J. Palmer: »Genrer og medier - et kort overblik«, in: MedieKultur, nr. 14, 1990.

11 Der henvises til M. Bruun Andersens artikel i nærværende nummer af $K \& K$.

12. Se J. Stigel: » Ten seconds of Advertising is a Long Story. Genre as an Important Part of Meaning in Advertising «, in: Larsen et. al. (eds.): Marketing and Semiotics, København 1991.

13. R. Kloepfer og H. Landbeck: Asthetik der Werbung, Frankfurt a.M. 1991.

14. Jr. R. Barthes: »Billedets retorik «, in: B. Fausing og P. Larsen (eds.): Visuel kommunikation 1-2, København 1980 (opr. 1964). 
15. Jf. R. Jakobson og M. Halle: Fundamentals of Language, Den Haag 1956; og R. Jakobson: »Closing Statement: Linguistics and Poetics«, in: T.A. Sebeok (ed.): Style in Language, Cambridge MA. 1960 (findes oversat i uddrag i Vindrosen nr. 7, 1967).

16. Jf. også K. Skretting: »Kikke, lytte, kjøpe. Reklame på kino og reklame på TV «, in: K. Skretting (red.): Kringkasting og kino, KULTs skriftserie nr. 15, Oslo 1993.

17. F.eks. Young \& Rubicam: Cross Cultural Consumer Characteristics. Segmentanalyse af European Consumers, København 1989.

18. Wells, op.cit. (se note 8). 
